\title{
MAGNIFICAT W WYBRANYCH PRZYKŁADACH MUZYCZNYCH
}

Muzykę, podobnie jak teatr, zalicza się do sztuk ulotnych, z którą obcuje się jedynie w momencie wykonywania. Nie ma możliwości, aby muzykę zobaczyć, ale tak jak rzeźba, malarstwo i architektura, potrafi ona oddziaływać na świadomość, poruszać umysły i serca, pozostawiając niezatarte piętno na słuchaczu oraz wykonawcy. Umożliwia ona przeżycie głębokich doświadczeń wewnętrznych. Wcale nie musi być organicznie związana $\mathrm{z}$ tekstem, może jedynie czerpać $\mathrm{z}$ niego inspirację. Według Harnoncourta muzyka jest mową dźwięków, która za pomocą odpowiedniego ładunku emocjonalnego wywołuje stany podobne do występujących podczas lektury tekstu i jego świadomej interpretacji ${ }^{1}$.

Na przestrzeni epok, od średniowiecza do współczesności, znajdujemy wiele muzycznych opracowań hymnu Magnificat. Temat ten podejmowali m.in.: John Dunstable (1380/1390-1452), Gilles Binchois (ca 1400-1460), Guillaume Dufay (ca 1400-1474), Jacob Obrecht (1457/8-1505), Orlando di Lasso (ca 1532-1594), Giovanni Pierluigi da Palestrina (ca 1525-1594), Claudio Monteverdi (1567-1643), Johann Sebastian Bach (1685-1750), Antonio Vivaldi (1678-1741), a w czasach współczesnych Luciano Berio (1925-2003) czy chociażby Krzysztof Penderecki (ur. 1933). ${ }^{2}$

1 Por. Nikolaus Harnoncourt, Muzyka mową dźwięków, tłum. Magdalena Czajka, Warszawa 1995, s. 8-9.

2 Za: Stanisław Garnczarski, Muzyczna ikona Maryi a wiara Kościoła, w: Wierzyć z Maryja i jak Maryja, red. Grzegorz Bartosik, Anna Gąsior, Janusz Królikowski, seria Biblioteka Mariologiczna, t. 17, Częstochowa 2014, s. 85. 
Również w Polsce nie brakuje wybitnych przykładów tego rodzaju kompozycji. Do grona najznakomitszych twórców, którzy posługiwali się europejskimi środkami techniki kompozytorskiej, z pewnością zaliczyć należy Mikołaja z Radomia, Jerzego Libana z Legnicy, Mikołaja Zieleńskiego, Marcina Mielczewskiego i Jacka Różyckiego.

Poświęćmy jednak nieco uwagi najwcześniejszym znanym w historii muzyki kompozycjom Magnificat. Pochodzą z epoki wczesnego średniowiecza, a dokładnie z przełomu VII i VIII wieku, kiedy rodził się śpiew romano-frankoński, zwany gregoriańskim (mylnie łączony z postacią św. Grzegorza Wielkiego, który stał na czele Kościoła w latach 590-604) ${ }^{3}$. Najstarszymi znanymi i zapisanymi przykładami muzycznymi są tu kompozycje pochodzące $z$ repertuaru śpiewu gregoriańskiego. Gregoriańskie Magnificat są świadectwem epoki, w której podstawowym punktem odniesienia był tekst Pisma Świętego, a jedynym znanym sposobem wypowiedzi muzycznej - forma monodyczna (podobnie jak w muzyce trubadurów i truwerów). Te dwa czynniki doskonale wzajemnie się przenikały, efektem czego jest kompozycja całego znanego nam dzisiaj proprium missae ${ }^{4}$. Bardzo rzadko zdarza się, aby w opracowaniu gregoriańskim jednemu tekstowi przyporządkowane było wiele melodii. Jeśli ma on wystąpić dwa razy, regułą jest, że jedna $\mathrm{z}$ kompozycji to tzw. tonus solemnis, a druga tonus simplex. Najbardziej uprzywilejowane są tematy maryjne. Za przykład niech posłuży tekst Ave Maria, gratia plena, który otrzymuje aż cztery melodie. Występuje jako: antyfona ${ }^{5}$, wykonywana przez

3 Święty papież Grzegorz Wielki ma wielkie zasługi na polu śpiewu liturgicznego. Zebrał on dokonania swoich poprzedników w Sakramentarzu, Antyfonarzu i Księdze Responsoriów. Jego działalność odnosi się do repertuaru starorzymskiego, będącego stadium kompozycyjnym poprzedzającym śpiew gregoriański. Zob. Erik Palazzo, A History of Liturgical Books from Beginning to the Thirteenth Century, Minnesota 1998, s. 21.

4 Są to własne części liturgii, do których należą: antiphona ad introitum, responsorium-graduale, alleluia (w okresie postnym i podczas liturgii za zmarłych zastępowane przez tractus), offertorium i antiphona ad communionem. Por. David Hiley, Gregorian Chant, Cambridge 2009, s. 24.

5 Ant. Ave Maria, w: Cantus Selecti, Solesmes 1949, s. 112. 
cały rok; responsorium krótkie ${ }^{6}$ na okres wielkanocny; melizmatyczne offertorium ${ }^{7} \mathrm{z}$ przebogatym wersetem solistycznym (znajduje się w Graduale Romanum w części Commune Beatae Mariae Virginis, co oznacza, że można śpiewać je przez cały rok) oraz sekwencja maryjna z tropem Ave Maria, gratia plena: Dominus tecum Virgo serena. ${ }^{8}$.

Magnificat jako kompozycja gregoriańska łamie wszelkie stereotypy. Nie dość, że ma osiem melodii, co wynika z psalmodycznego charakteru tekstu i jego strukturyzacji, to wykonuje się je codziennie, i to w specjalnie uroczystej formie z tzw. initium (początek wersetu zwany intonatio) oraz mediatio ornata (kadencja po pierwszym hemistychu). Wymienione elementy odróżniają Magnificat (oraz inne nowotestamentalne kantyki: Nunc dimmitis i Benedictus) od reszty psalmodii. Przy wykonywaniu wszystkich innych psalmów incipit (intonatio) stosuje się tylko na początku - bezpośrednio po antyfonie - aby gładko połączyć finalis (ostatni dźwięk antyfony) z tenorem psalmowym, na którym recytuje się większość tekstu (z wyjątkiem fleksy i dwóch kadencji - mediatio, terminatio). W przypadku Magnificat stosuje się intonatio w każdym wersecie, aby podkreślić szczególny charakter tekstu i dodatkowo nadać mu bardziej uroczystą (ozdobniejszą) formę:

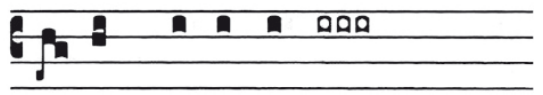

Ma-gní. ficat

Przykład intonatio w VII tonie ${ }^{9}$

Magnificat obecne jest w codziennej Liturgii godzin, a konkretnie w śpiewanych późnym popołudniem bądź wieczorem Nieszporach, po lekcji (lectio brevis) i responsorium (responsorium brevis post

${ }^{6}$ Resp. Ave Maria, w: Antiphonale Monasticum, Parisiis-Tournaci-Romae 1934, s. 1182.

7 Of. Ave Maria, w: Offertoriale Triplex, Solesmes 1985, s. 13.

8 Seq. Ave Maria, w: Cantus Selecti, dz.cyt., s. 159.

9 Przykład zaczerpnięty z Antiphonale Romanum, t. II, Ad Vesperas in dominicis et festis, Solesmes 2009, s. 750. 
lectionem) i przed modlitwami (preces). Z uwagi na swą psalmodyczną naturę (wersy binarne, każdy złożony z dwóch hemistychów, po pierwszym - gwiazdka - mediatio, po drugim - terminatio wraz z przyporządkowaną dyferencją) Magnificat organicznie związane jest $\mathrm{z}$ antyfoną (zwaną antiphona ad magnificat). Integralne wykonanie kompozycji nazywamy śpiewem antyfonalnym (z gr. ante fonium „przeciwgłos”): psalmodię śpiewaną naprzemiennie przez dwa chóry poprzedza i kończy odpowiednia antyfona skomponowana w jednym z modusów. To właśnie modus antyfony determinuje ton, w którym należy zaśpiewać kantyk, a odpowiednie terminatio płynnie łączy ostatni hemistych tekstu z pierwszym dźwiękiem antyfony przy jej repetycji. Każdy wers tekstu rozpoczyna się od intonatio (initium), a kadencja środkowa (mediatio) jest ozdobiona. Często w księgach liturgiczno-muzycznych publikuje się gotowe klauzule muzyczne z podłożonym tekstem, w zależności od liczby i rodzaju akcentów (akcent paroksytoniczny i proparoksytoniczny). Ton $\mathrm{V}$ ma mediatio jednoakcentową z jedną sylabą przygotowującą (clausalae unius accentus, cum una syllaba praeparationis), tony II, IV i VIII mediatio jednoakcentową z trzema sylabami przygotowującymi (clausulae unius accentus, cum tribus neumis praeparationis), tony I i VI - mediatio jednoakcentową z trzema sylabami przygotowującymi (clausulae unius accentu, cum tribus neumis praeparationis et superveniente anticipata) i epentezą wyprzedzającą akcentowaną, a tony III i VII mediatio dwuakcentową bez żadnej sylaby przygotowującej (clausulae duplicis accentus). Drugi z akcentów stanowi epenteza wyprzedzająca akcentowana. Częstą praktyką, szczególnie we wspólnotach o charakterze monastycznym, jest tworzenie dłuższej pauzy w miejscu gwiazdki po pierwszym hemistychu, a dość płynne łączenie drugiego hemistychu z początkiem kolejnego wersu. Praktyka taka, właściwa psalmodii, sprzyja medytacji wypowiadanego słowa, a naprzemienność wykonawcza (alternacja) podtrzymuje modlitewne skupienie i ogniskuje uwagę wykonawców na tekście. 


\section{Toni I, VI}

Clausula unius accentus, cum tribus neumis proparationis et superveniente anticipata.

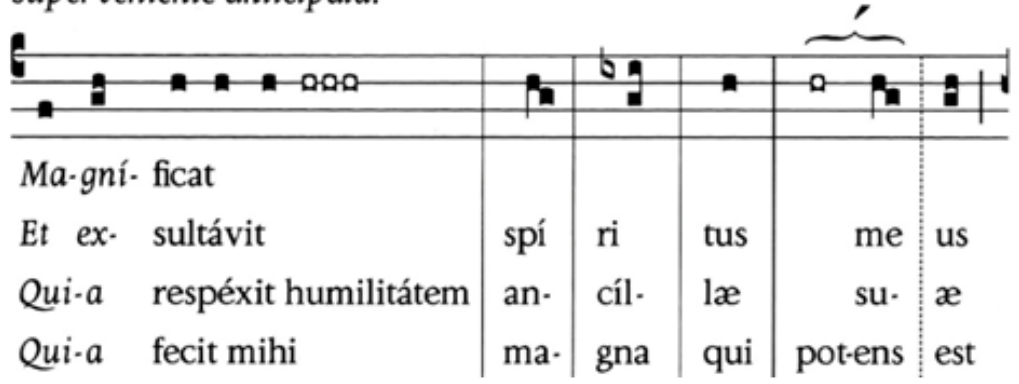

Przykład kadencji mediatio ornata dla Magnificat w I i VI tonie ${ }^{10}$

Śmiało można stwierdzić, że wszystkie późniejsze kompozycje wykorzystujące tekst Magnificat mają charakter topiczny, gdyż ich autorzy świadomie lub nieświadomie odwołują się do archetypu. W przypadku śpiewu gregoriańskiego słowa te nabierają nie tylko symbolicznego sensu, gdyż fakty historyczne niezbicie dowodzą, że stał się on bazą dla rozwoju historii muzyki ${ }^{11}$. Pierwsza polifonia (muzyka wielogłosowa) w nim widziała swoje źródło melodyczno-rytmiczne. Wraz z jej rozwojem melodia gregoriańska, użyta w długich wartościach rytmicznych w jednym z głosów, stanowiła cantus firmus, na którym opierała się konstrukcja wielogłosowa. W poniższym tekście w syntetycznym ujęciu zaprezentowane zostanie teologiczne podejście do tekstu Magnificat (szczególnie werset trzeci Quia respexit humilitatem ancilae suae) $\mathrm{w}$ trzech kompozycjach stanowiących ogromny wkład w muzykę europejską, autorstwa Mikołaja z Radomia, Jerzego Libana z Legnicy i Mikołaja Zieleńskiego.

\footnotetext{
10 Tamże, s. 745.

11 Wielki słownik wyrazów obcych PWN, red. Mirosław Bańko, Warszawa 2005, s. 1265, podaje następującą definicję słowa topos: „motyw lub temat pojawiający się pod różnymi postaciami w literaturze wielu epok i kultur, będący świadectwem ciągłości i wspólnoty kulturowej oraz archetypicznego charakteru kultury”.
} 
Wraz z rozwojem muzyki wielogłosowej śpiew gregoriański zaczął powoli zatracać swoją pierwotną funkcję proklamacji tekstu na rzecz obecności w jednym z głosów jako cantus firmus. Do najcenniejszych dzieł reprezentujących europejski poziom kultury muzycznej i nowoczesne środki techniki kompozy torskiej należy pierwsze rdzennie polskie wielogłosowe opracowanie Magnificat autorstwa Mikołaja z Radomia, pochodzące z pierwszej połowy XV wieku (nie znamy dat życia kompozytora). O jego twórcy nie wiemy prawie nic, poza tym, że był jedynym znanym polskim kompozytorem średniowiecznym tworzącym muzykę świecką i religijną w stylach burgundzkim, włoskim i niderlandzkim, co świadczy o otwartości naszego kraju na międzynarodowe zdobycze kultury muzycznej. Dzieło Magnificat, obok panegiryku na cześć pary królewskiej Hystoriographi aciem mentis, jest jego najbardziej znanym utworem. Trzygłosową obsadę wykonawczą stanowią „alt, chór mieszany i dwa puzony, dwie wiolonczele ad lib.”. Utwór zasługuje na zainteresowanie przede wszystkim dlatego, że w pionierski sposób wykorzystuje technikę fauxbourdon. Są to równoległe pochody akordów w pierwszym przewrocie przesuwane względem siebie w jednym kierunku. Inną charakterystyczną cechą jest bardzo przemyślana i wewnętrznie spójna koncepcja formalna, w sferze melodyki mocno nawiązująca do śpiewu gregoriańskiego ${ }^{12}$.

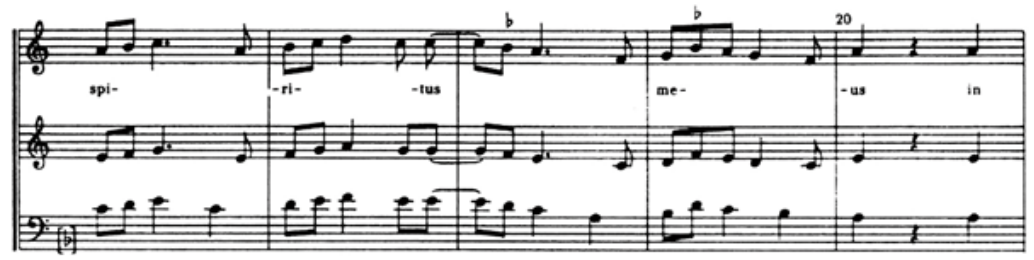

Przykład techniki fauxbourdon (Mikołaj z Radomia, Magnificat, t. 16-20) ${ }^{13}$

\footnotetext{
12 Zob. Stanisław Dąbek, Koncepcja formy i brzmienia «Magnificat» Mikołaja $z$ Radomia, „Roczniki Teologiczno-Kanoniczne” 34 (1987), z. 7, s. 14.

13 Mikołaj z Radomia, Magnificat i inne utwory, Kraków 1966, s. 7.
} 

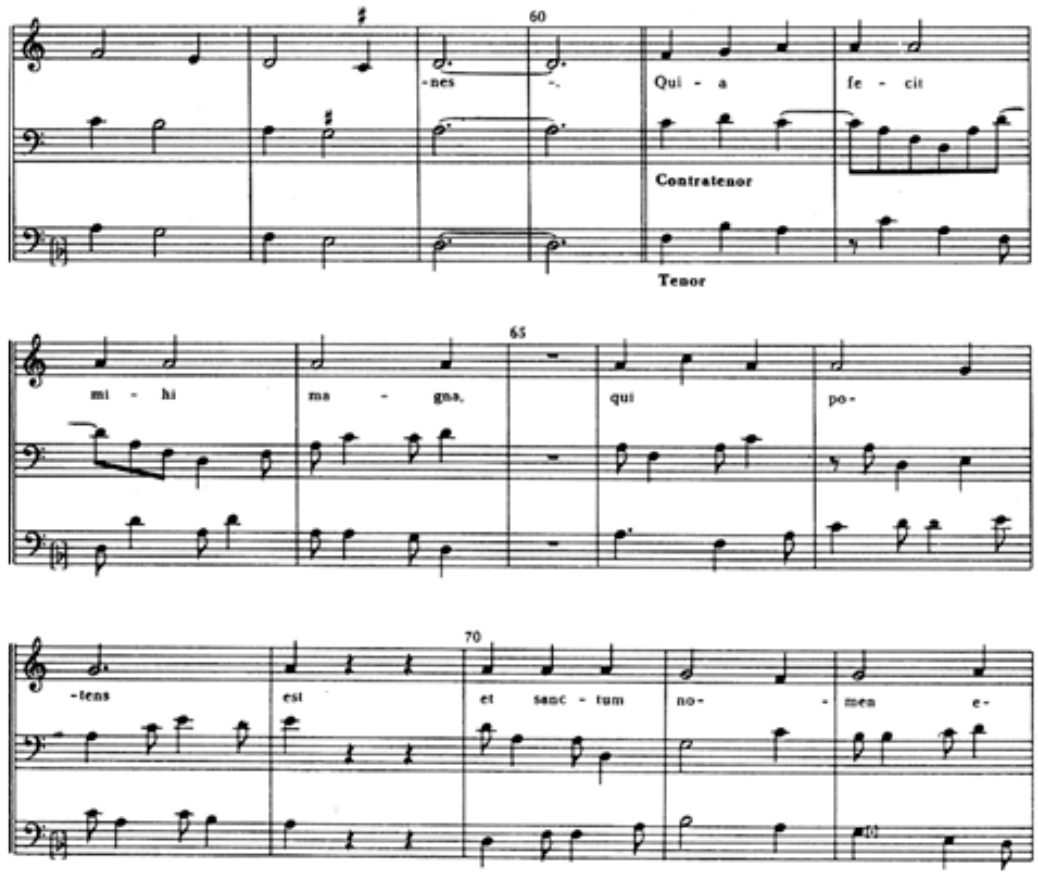

Mikołaj z Radomia, Magnificat, t. $57-72^{14}$

Magnificat Mikołaja z Radomia składa się z jedenastu odcinków odpowiadających wersom tekstu, oś symetrii stanowi wers szósty (Fecit potentiam...). W związku z zastosowaniem różnych technik kompozytorskich tworzą się wokół osi symetrii pary poszczególnych wersów opracowanych w podobny sposób. Stanisław Garnczarski, który zajmował się szczegółowo budową formalną kompozycji, stwierdza ponadto, że wers trzeci Quia respexit humilitatem ancillae suae zachowuje autonomię i pod względem opracowania nie łączy się $\mathrm{z}$ żadnymi innymi ${ }^{15}$. Odwołanie się do wczesnochrześcijańskiej literatury patrystycznej ujawnia, że ma to ścisły związek z cnotą pokory

14 Mikołaj z Radomia, dz.cyt., s. 9.

15 Zob. Stanisław Garnczarski, dz.cyt., s. 86. 
(u Augustyna aspekt poznania, sądu i pokory). Z muzycznego punktu widzenia kompozytor, szczególnie ozdobnie opracowując dwa słowa: respexit (wejrzał - motyw wznoszący na sylabie akcentowanej) i ancillae suae (swoją sługę - motywy opadające), dał teologiczny klucz do odczytania kompozycji. Dla nas jednak najciekawsze, w kontekście prowadzonych rozważań, są wersy czwarty i ósmy, ze względu na obecność melodii tonu psalmowego Magnificat w najwyższym głosie, które są potwierdzeniem topicznego charakteru kompozycji.

Wybitnym przedstawicielem renesansu, którego opera omnia wypływa z żywej praktyki śpiewu gregoriańskiego, jest Jerzy Liban z Legnicy, autor dwóch traktatów teoretycznych wydanych w Krakowie: De accentuum ecclesiasticorum exquisita ratione (ca 1539) oraz De musicae laudibus oratio (1540). Jerzy Liban (1464 - po 1546) był absolwentem Akademii Krakowskiej, następnie studiował w Kolonii. Po powrocie otrzymał posadę wykładowcy w Krakowie i równocześnie pracował w szkole przy kościele Mariackim jako nauczyciel, kantor, a później jej rektor ${ }^{16}$. Jest autorem dwunastu utworów (w tym bardzo znanej ant. Ortus de Polonia ku czci św. Stanisława $\mathrm{BM}$ ), wśród których osiem to Magnificaty w ośmiu tonach kościelnych. Wykonywane są $\mathrm{w}$ technice alternatim polegającej na przeciwstawianiu chóru mieszanego (w obsadzie czterogłosowej: dyszkant, alt, tenor i bas) monodycznej strukturze śpiewu gregoriańskiego. Kompozycje te są ilustracjami muzycznymi do rozważań Libana o tonach psalmowych w traktacie De musicae laudibus oratio. Ich charakterystyczną cechą jest ścisła imitacja najwyższej próby. Każdy głos rozpoczyna się tym samym czołem tematycznym, nawiązującym do psalmowego initium, przeprowadzonego przez pozostałe elementy struktury polifonicznej. Melika nawiązuje do melodyki tonu psalmowego. Opracowania polifoniczne otrzymują każdorazowo pierwszy, czwarty, siódmy, ósmy i jedenasty wers, natomiast w gregoriańskiej wersji monodycznej pozostają pary wersów: drugi i trzeci - Quia respexit humilitatem ancillae suae, piąty i szósty oraz

\footnotetext{
16 Por. Katarzyna Morawska, Renesans 1500-160o, seria Historia muzyki polskiej, t. 2, Warszawa 1994, s. 164.
} 
dziewiąty i dziesiąty ${ }^{17}$. Wspomniany wers trzeci już poprzez sam fakt pozbawienia go opracowania polifonicznego jest uboższy i ilustruje uniżenie tej, która przyjęła Boże Słowo do swojego łona.

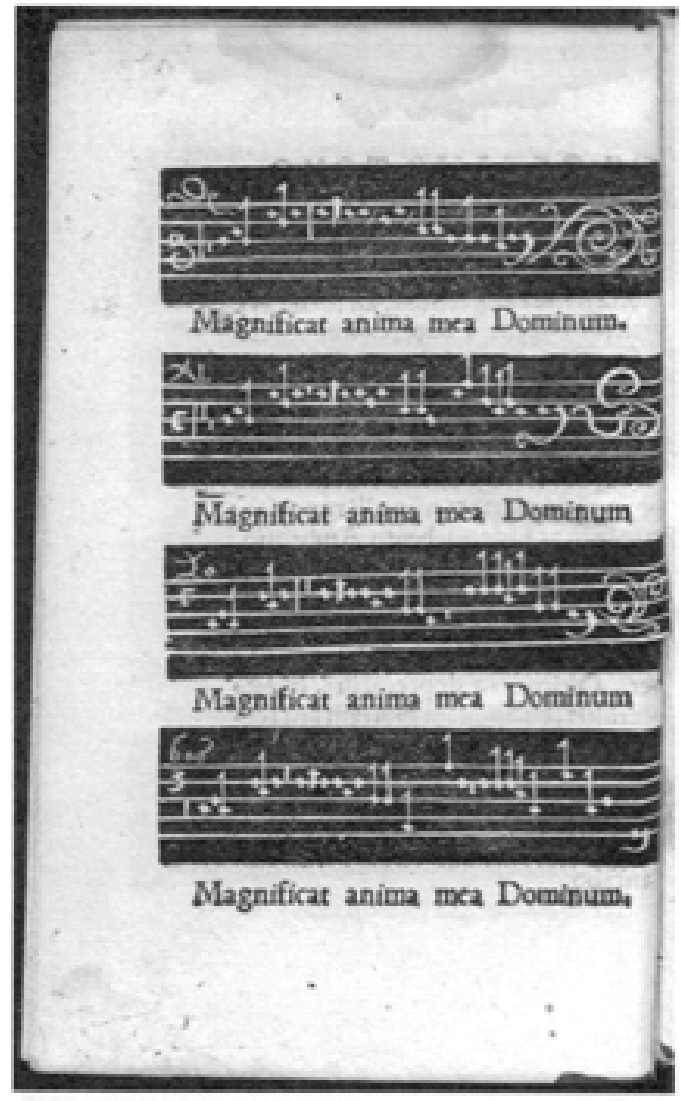

Jerzy Liban, Magnificat, ton VIII G ${ }^{18}$

17 W rzeczywistości jest to tylko propozycja wykonawcza wydawcy i rewizora Jana Węcowskiego - poparta gruntowną znajomością struktury kompozycji, a także teologicznego znaczenia tekstu. Por. Jerzy Liban z Legnicy. Opera omnia, transkrypcja i opracowanie Jan Węcowski, Legnica-Warszawa 2013, s. 42-89.

18 Przykład zaczerpnięty z: Jerzy Liban - De musicae laudibus oratio, red. Jerzy Morawski, Kraków 1975. 
Podobne podejście teologiczne zauważyć możemy u kompozytorów przełomu renesansu i baroku. Nie może tu zabraknąć odniesienia do Mikołaja Zieleńskiego, którego sztandarowym dziełem jest dwunastogłosowe Magnificat na trzy czterogłosowe chóry mieszane. Zieleński (ca 1550 - ca 1616) był kompozytorem, organistą i kapelmistrzem na dworze polskiego prymasa Wojciecha Baranowskiego w Łowiczu. Jest autorem dwóch potężnych zbiorów utworów liturgicznych, które ukazały się nakładem Jacobusa Vincentiego w Wenecji w 1611 roku: Offertoria totius anni i Communiones totius anni. W swych kompozycjach wykorzystywał zarówno zdobycze rozwiniętej polifonii renesansowej, jak i techniki wczesnobarokowe, przede wszystkim zaś - technikę polichóralną (wielochórową, zwaną też cori spezzati), która polega na dialogowaniu dwóch lub więcej grup chóralnych i jest charakterystyczna dla szkoły weneckiej (technika alternatim wywodzi się ze śpiewu gregoriańskiego i w szkole weneckiej była rozwijana). Powstała ona prawdopodobnie w bazylice patriarchalnej św. Marka, co związane jest z jej układem przestrzennym oraz usytuowaniem dwóch instrumentów organowych na przeciwległych krańcach prezbiterium. W Europie w tamtym okresie polichóralność stosowało wielu kompozy torów, jednak na gruncie polskim twórczość Zieleńskiego jest zjawiskiem absolutnie niepowtarzalnym. W dwunastogłosowym Magnificat bardzo wyraźnie widać upodobanie kompozytora do ilustrowania treści semantycznej tekstu za pomocą dostępnych mu środków kompozytorskich. Poprzez różnicowanie wysokości, barwy i brzmienia poszczególnych chórów, tworzą się swoiste figury retoryczne. Wers Et exultavit spirtus rozpoczyna się w niskim rejestrze, przechodzi przez chór średni po to, by na słowach in Deo salutari meo osiągnąć najwyższe dźwięki w partii sopranu. Innym przykładem może być fragment omnes generationes, gdzie ambitus pomiędzy najwyższym a najniższym głosem sięga trzech oktaw, a we fragmencie Gloria Patri dochodzi do prawie czterech oktaw (trzy oktawy plus interwał kwinty). Charakterystycznymi retorycznie są również fragmenty a progenie in progenies, w których dialog poszczególnych chórów ilustruje przechodzenie z pokolenia na pokolenie. 


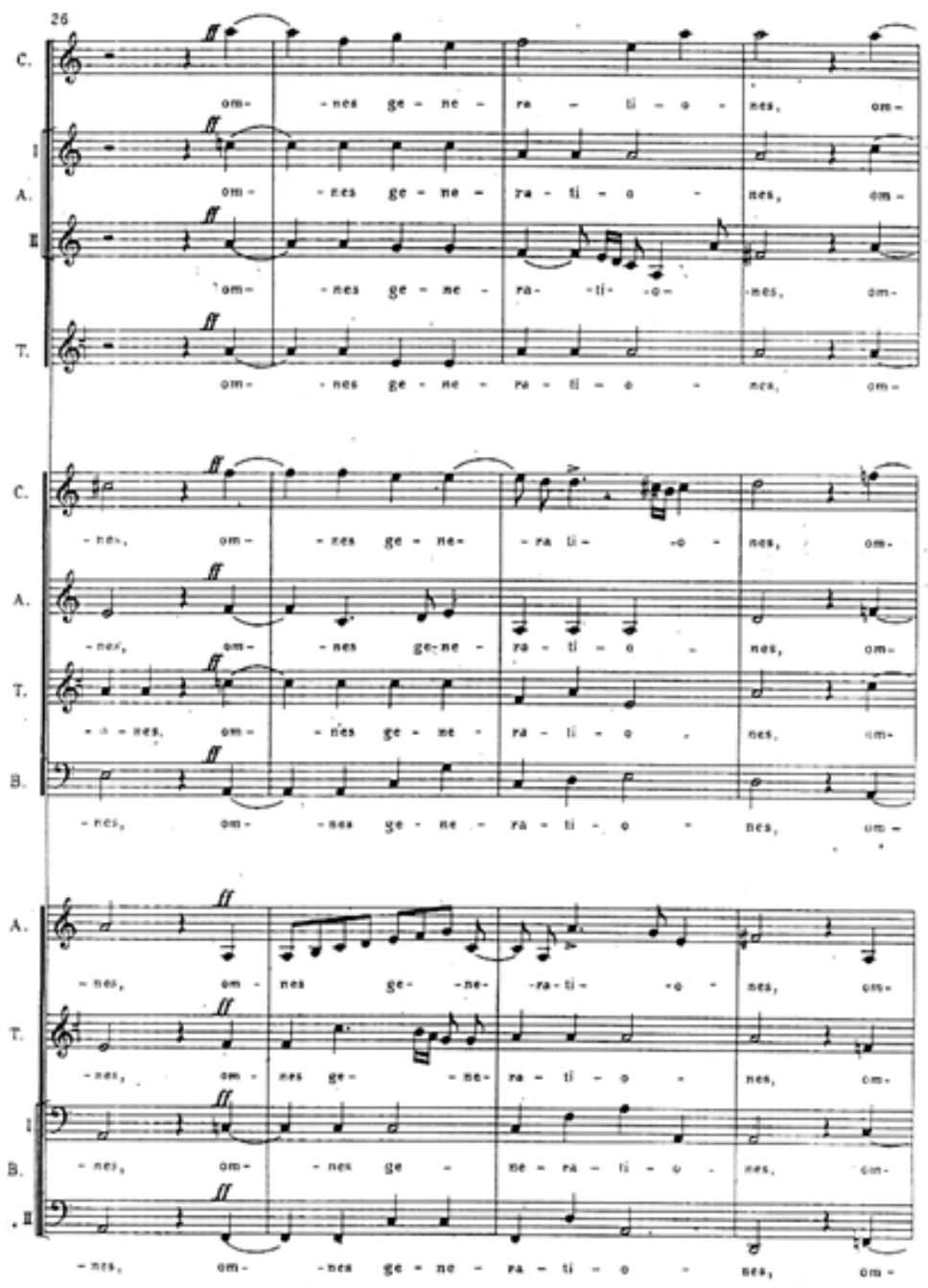

Mikołaj Zieleński, Magnificat, t. 26-29 ${ }^{19}$

19 Mikołaj Zieleński, Offertoria et communiones totius anni, oprac. Katarzyna Morawska, seria Monumenta Musicae in Polonia, seria D, Bibliotheca Antiqua, Kraków 1983, s. 228. 
Okazuje się, że używając techniki polichóralnej, można również zilustrować pewne myśli teologiczne. Rzeczony wers trzeci jest jedynym przypadkiem, w którym kompozytor daje autonomię najniższemu chórowi i od niego rozpoczyna wprowadzanie nowego materiału czy motywu muzycznego, nie zazębiając go przy tym z partią jednego z wyższych zespołów. We wspomnianym fragmencie partia głosu żeńskiego - altu - prawie w całości utrzymana jest w oktawie małej typowej dla średnich głosów męskich.
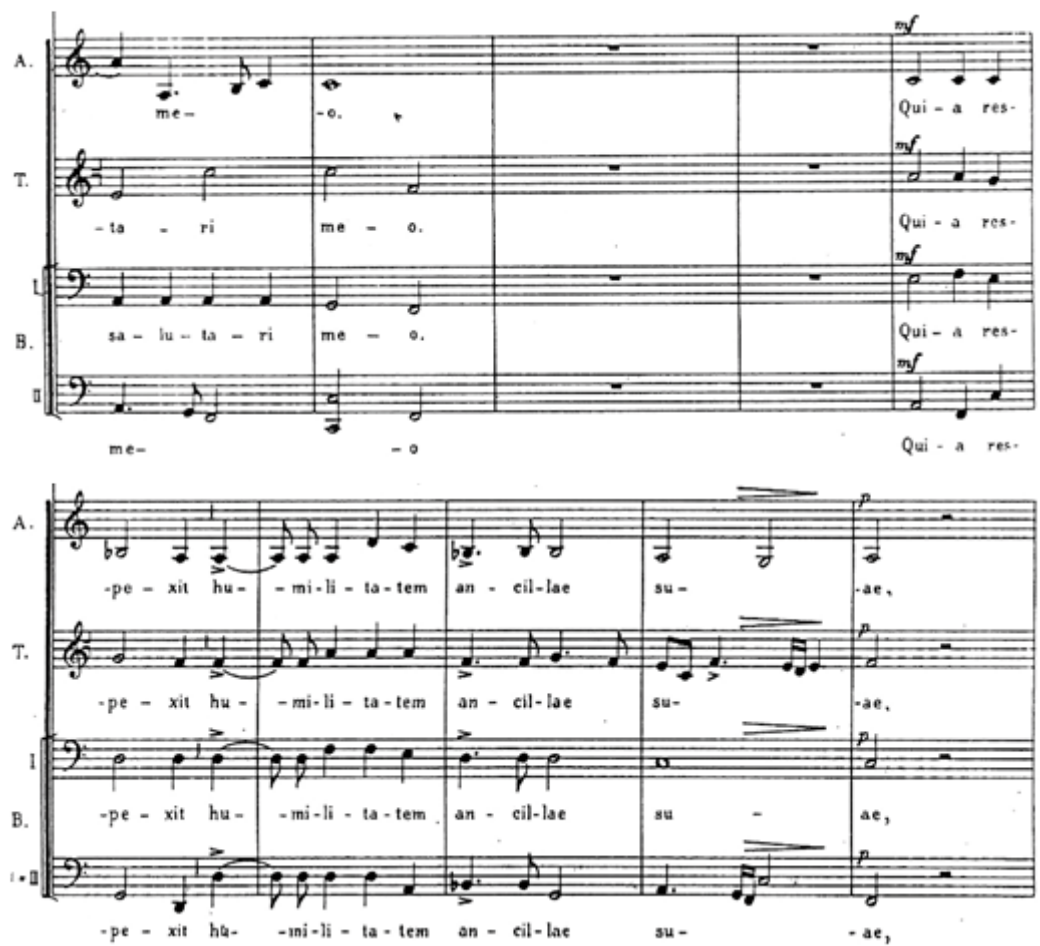

Mikołaj Zieleński, Magnificat, t. 12-21 (fragment partii najniższego chóru) ${ }^{20}$

20 Tamże, s. 225-226. 
Niewiele jest przesady w stwierdzeniu, że europejska kultura muzyczna wyrosła na kanwie zachodniej monodii liturgicznej. Przedstawione przykłady wczesnych opracowań Magnificat świadczą o archetypicznym i topicznym charakterze polskiej kultury muzycznej, o jej wielkiej otwartości na europejskie zdobycze na polu technik kompozytorskich. Są też potwierdzeniem teologicznego podejścia do materii muzycznej w przypadku konkretnych ujęć muzycznej ikony Maryi i wiary Kościoła. Zasmuca jedynie fakt, że dawna muzyka polska, szczególnie sakralna, jest nieznana i niedoceniana, a przecież kryje w sobie tak wiele doniosłych treści i niczym nie ustępuje kompozycjom zachodnim. Warto się w nią wsłuchiwać.

\section{Summary \\ Selected examples of „The Magnificat” in music}

The author presents examples of early musical adaptations of „The Magnificat”, which attest to the archetypical character of Polish musical culture as well as to its great openness towards European advances in the field of composition techniques. These examples also reveal a theological approach to the musical matter, which is present in particular works conceptualizing Virgin Mary and the Church's faith in a musical manner. 